Annals of Warsaw University of Life Sciences - SGGW

Land Reclamation No 42 (1), 2010: 79-91

(Ann. Warsaw Univ. of Life Sci. - SGGW, Land Reclam. 42 (1), 2010)

\title{
Stream networks and knickpoints in the Sanjiangyuan Region
}

\author{
ZHAOYIN WANG ${ }^{1}$, GUO-AN YU ${ }^{2}$, GARY BRIERLEY ${ }^{3}$, LE LIU ${ }^{4}$ \\ ${ }^{1}$ State Key Laboratory of Hydroscience and Engineering, Tsinghua University, China \\ ${ }^{2}$ Institute of Geographical Sciences and Natural Resources Research, Chinese Academy of Sciences \\ ${ }^{3}$ School of Environment, University of Auckland \\ ${ }^{4}$ Department of Hydraulic Engineering, Tsinghua University, China
}

\begin{abstract}
Stream networks and knickpoints in the Sanjiangyuan Region. The source area of the Lancang (Mekong), Yangtze and Yellow rivers is named in Chinese Sanjiangyuan (source of three rivers). Geographical characteristics of these rivers, and various rivers at the margin of the Qinghai-Tibetan Plateau (Jialing, Minjiang, Dadu, Yalong and Jinsha) are summarized from field investigations along with digital elevation model (DEM) analyses and satellite images. Uplift of the Qinghai-Tibetan Plateau has resulted in an asymmetrical distribution of tributaries for stream networks at the margins of the plateau. Almost all tributaries join the trunk stream from the northwest. Three types of drainage network are evident: plume, nervation and dendritic. In general, plume networks have a large number of first order streams. Nervation networks have a main stream and parallel tributaries. Dentritic networks are characrterized by continuous bifurcation and have a branch-like appearance. Most stream networks in the Sanjiangyuan region are of the nervation type. Several large knickpoints are evident along the longitudinal profiles of the Yellow and Yangtze Rivers. Channel aggradation immediately upstream of these knickpoints marks a transition in river processes from vertical bed evolution (i.e. incision) to horizontal channel adjustment (and associated braided and anabranching channels).
\end{abstract}

Key words: Qinghai-Tibetan Plateau, knickpoint, drainage network, Sanjiangyuan, step-pool.

\section{INTRODUCTION}

The 6,300 km Yangtze River and 5,464 km Yellow River are the longest and second longest rivers in China. The Lancang River (Mekong River) is the largest international river in Asia. The source area of the three rivers is named in Chinese Sanjiangyuan (source of three rivers). It extends on the Qinghai-Tibet plateau from N31 $1^{\circ} 39^{\prime}$ to $\mathrm{N}^{2} 6^{\circ} 16^{\prime}$ and from $\mathrm{E} 89^{\circ} 24^{\prime}$ to $\mathrm{E} 102^{\circ} 23^{\prime}$. Altitude varies from 2,000-5,000 m, with a mean altitude of about $4,000 \mathrm{~m}$. The total area of Sanjiangyuan is $360,000 \mathrm{~km}^{2}$. About $49 \%$ of Yellow River water, $15 \%$ of Lancang River water and $2.5 \%$ of the Yangtze River water come from this region (http://www.snowland-great-rivers. org/threerivers.htm). There are more than 180 streams, 16,500 lakes, a total of $73,300 \mathrm{~km}^{2}$ of swamp, and numerous snow mountains and glaciers with a total area of 2,400 km $\mathrm{km}^{2}$ in the region.

Northward movement of the Indian Plate, and its collision with the Eurasian Plate, has uplifted the Qinghai-Tibetan Plateau, which is referred to as the 'third 
pole' or the 'roof of the world'. Uplift of the Qinghai-Tibetan Plateau has created drier and colder conditions (Tang and Dong 1997). It has also brought about large-scale and profound environmental changes in surrounding areas, including the formation of deserts in northwestern China (Dong et al. 1994).

Various stream network patterns have formed under different environmental conditions in the region. Rather than developing a typical dendritic (tree-like) form, stream networks have a nervation (vein-like) form (Wang et al. 2009b). Hortonian laws of stream numbers, lengths and drainage areas vary markedly across the region, with notable differences in glaciated and non-glaciated areas. Indeed, glacial and fluvial erosion are the main driving forces in the development of complex stream-lake network in the region.

Deformation of landscapes at the plateau margin has resulted in steep, highly dynamic rivers, many of which are characterized by typical step-pool system sequences (Chin 2002; Costa and Schuster 1988; Korup 2004; Wang et al. 2009a). An approximate topographic equilibrium has been maintained as rapid fluvial incision into bedrock and headward migration of knickpoints strives to keep balance with tectonic uplift (Korup et al. 2006; 2009). This has further accentuated slope instability, so landslides and debris flows are common (Ouimet et al. 2007). High sediment loads carried by the Yellow, Yangtze and Lancang Rivers reflect high rates of landscape denudation. This has increased sediment transport by rivers and offshore deposition. Landscape instability brought about by incision and mass movements, and asso- ciated high sediment transport rates, has resulted in various ecological problems in the Sanjiangyuan region.

This paper overviews summary results from field and DEM-based analyses on stream network patterns in the Sanjiangyuan region and knickpoint processes at the margin of the Qinghai-Tibetan Plateau. Results from these scientific investigations will hopefully provide effective guidance for integrated management of natural resources in the Sanjiangyuan region, aiding sustainable development programmes that strive to reconcile ecological protection with sustainable use of land and water resources.

\section{METHODS}

Geographical and geometrical characteristics were measured in the field using Global Positioning System (GPS) and laser range meter. A 1995 digital map of China with a scale ratio of 1:250.000, 1960s topographic maps with a scale ratio of 1:50 000, and 2004 digital topographic SRTM-3 data were used to construct longitudinal profiles and cross sections of various rivers. This was completed using ARCGIS. GoogleEarth was used to provide global satellite images at varying resolutions. In this study, the "eye altitude" was fixed to ensure that all data were collected at the same resolution.

\section{ASYMMETRICAL DISTRIBUTION OF TRIBUTARIES}

According to the British Geological Survey, the Indian Plate moves northward at a rate of $5 \mathrm{~cm} /$ year (Chen and Gavin, 2008). Its collision with the Eurasian Plate has resulted in the uplift of the Himalaya and the Qinghai-Tibetan Plateau, and 
associated earthquake activity. The rate of horizontal movement is about $5 \mathrm{~cm} / \mathrm{yr}$ at Himalaya, $4 \mathrm{~cm} / \mathrm{yr}$ in the source area of the Lancang and Yangtze Rivers, to about $2 \mathrm{~cm} / \mathrm{yr}$ at the Qilian Mountain. As a result the Himalaya rises at a rate of $21 \mathrm{~mm} / \mathrm{yr}$ while the Qilian Mountains rise at a rate of $5 \mathrm{~mm} / \mathrm{yr}$. The Sichuan basin, located to the east of the plateau, is stationary. This pronounced variability in the rates of horizontal movement has resulted in many active faults, such as the Kalakunlun Fault to the west, Kunlun fault in the center, Altyn fault to the north, and Xianshuihe and Longmenshan faults to the east. The Wenchuan earthquake on May 12, 2008 occurred along the Longmenshan fault.

Streams along the east margin of the Qinghai-Tibetan Plateau and the Longmenshan Fault are shown on Figure 1. The four major rivers of Sichuan Province (Minjiang, Tuojiang, Fujiang and
Jialing) are all tributaries of the Yangtze River. The rising plateau has increased the gradient of these rivers, inducing incision that often extends over $2 \mathrm{~km}$ deep. Uplift has caused dramatic changes to stream networks. All major rivers in this region flow from northwest to southeast, reflecting the uplift of the plateau and relatively stationary position of the Sichuan Basin to the east.

Asymmetry of stream networks is also evident in small watersheds. Figure 2 shows the stream network of the Xihanshui River (the upstream area of the Jialing River) on the northeastern margin of the plateau. Once more, all large tributaries join the river from the northwestern side, creating a very asymmetrical stream network. More than $90 \%$ of the drainage area is on the western side of the river. This situation is repeated for many stream networks at the margins of the Qinghai-Tibetan Plateau.

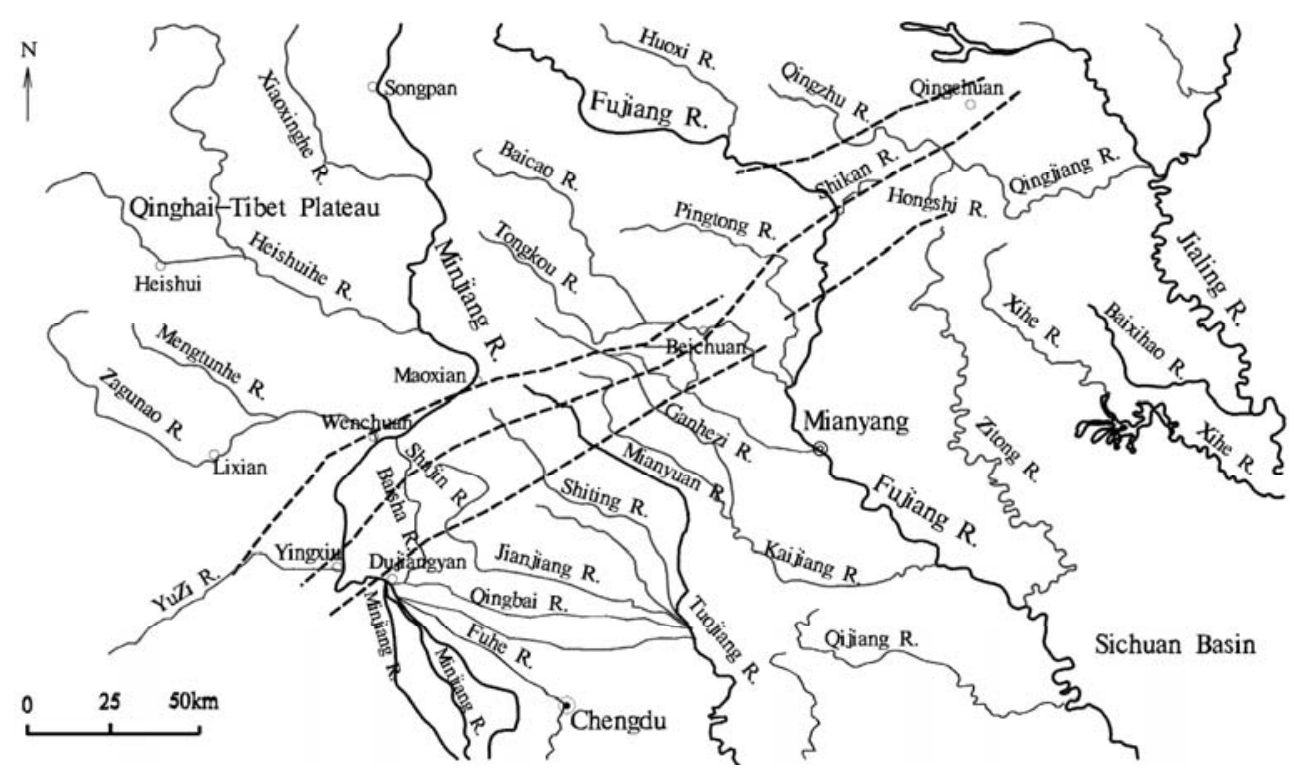

FIGURE 1. Streams on the east margin of the Qinghai-Tibetan Plateau and the Longmenshan Fault 


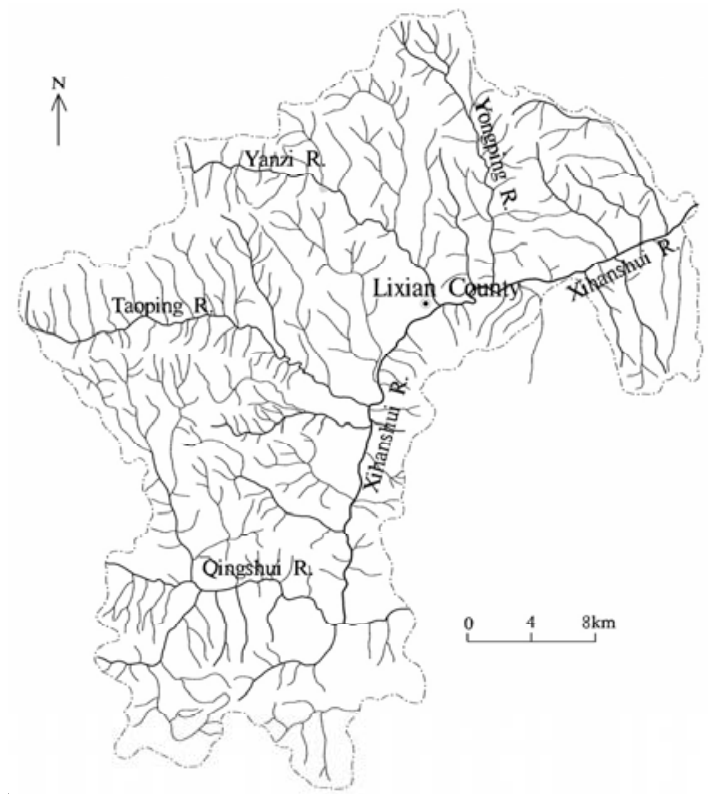

FIGURE 2. Asymmetrical distribution of tributaries and drainage area of the Xihanshui River

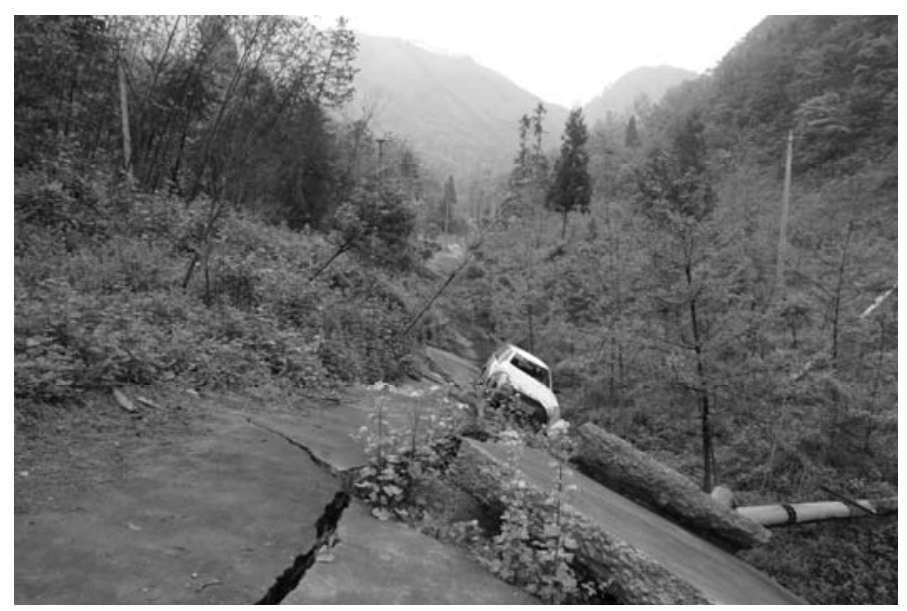

FIGURE 3. Wenchuan earthquake changed the bed slope and cut off the flow in a tributary stream of the Shenxi Ravine in the Minjiang River basin

Shenxi Ravine, a tributary stream in the Minjiang River basin, is located along the Longmenshan Fault which separates the Qinghai-Tibetan Plateau to the northwest and the Sichuan basin to the south- east (Fig. 3). The most recent uplift phase of the plateau, the Wenchuan earthquake, induced a $4 \mathrm{~m}$ vertical displacement along this fault, as the area to the northwest was uplifted. It triggered numerous landslides 
and avalanches (Wang et al. 2009a). Prior to the earthquake, the stream shown in Figure 3 was a perennial stream that flowed into the Shenxi Ravine. Tectonic motion cut off surface runoff and changed the slope of the stream. Such episodes have been repeated many times during the millions of years over which uplift of the Qinghai-Tibetan Plateau has taken place. This has resulted in very asymmetrical stream networks.

\section{STREAM NETWORKS ON THE QINGHAI-TIBETAN PLATEAU}

Horton (1945) pioneered quantitative studies of river morphology by introducing his laws of stream number, $N_{m}$, i.e.

$$
N_{\omega}=A e^{-B \omega}
$$

where $\omega$ is stream order; $N_{\omega}$ is the number of $\omega$-th order streams; and A and B are constants. This empirical law was not derived from basic theories in physics or other fundamental theories. However, although arguments about the Horton's Laws persist, the validity of equations has been independently verified and they have been accepted as basic laws in river morphology (Ciccacci et al. 1992; Kinner and Moody 2005).

The bifurcation ratio, $R_{B}$, characterizes the ratio of the number of streams of differing stream orders according to the following equation:

$$
R_{B}=\frac{N_{\omega}}{N_{\omega+1}}=e^{B}
$$

According to Horton's Law, $R_{B}$ is invariant with stream orders and networks (i.e. Horton's ratio is the same for different rivers and for different stream orders). However, various researchers have questioned the universality of Horton's law. For instance, Kirchner (1993) argued that Horton's ratio may vary for different stream networks. Also, Liu and Wang (2008) found that Horton's ratio is constant only for the stream orders higher than 8. For lower stream orders, Horton's ratio varies with stream order and is very different for different river networks. For example, a large number of first order streams flow into a second order stream in a plume network (Fig. 4a). In contrast, a nervation network has a main stream and parallel tributaries (Fig. 4b). Finally, dendritic networks have continuous bifurcation and look like tree branches (Fig. 4c); these are the notionally 'typical' networks to which Horton's Law applies.

Most stream networks in the Sanjiangyuan region are nervation, with some plume networks. For example, Figure 5a shows a plume stream network in the source of the Dadu River, a tributary of the Yangtze River. Figures $5 b$ and c show nervation networks in the source of the Yellow River near Kesheng Town and Maqin County.

Liu and Wang (2008) calculated Horton's ratios for typical plume and nervation networks in the loess plateau area of China and typical dendritic networks in northeast China (Fig. 6). The bifurcation ratio for plume networks is more than 10 for stream orders less than 3 . This is much greater than the value for dendritic networks (about 4) and nervation networks (about 5). For stream orders higher than 4 , the bifurcation ratio reduces and converges for all three types of networks, and approaches 4 for $8^{\text {th }}$ order streams. The ratio for dendritic networks is almost 
a

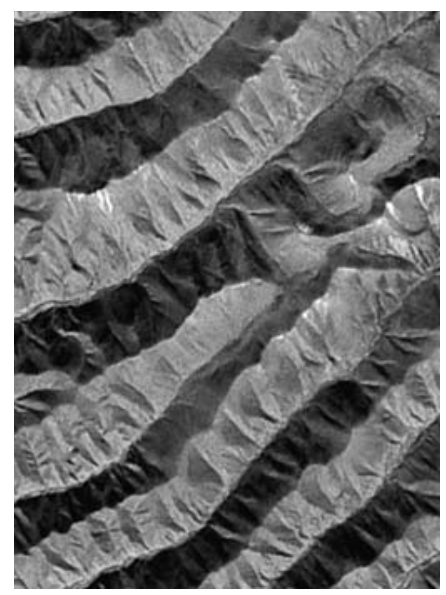

b

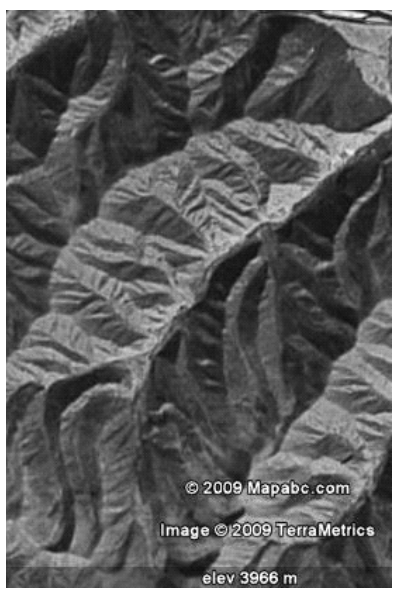

C

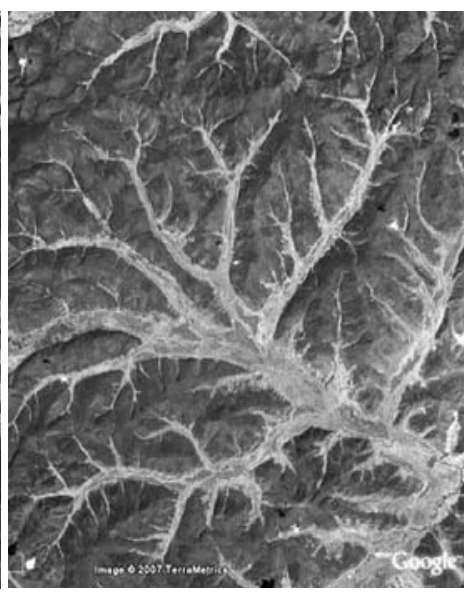

FIGURE 4. $\mathrm{a}$ - Plume network in the source region of the Dadu River; $\mathrm{b}$ - Nervation network near Dari County; c - Typical dendritic network in the Songhua River basin in northeastern China

a

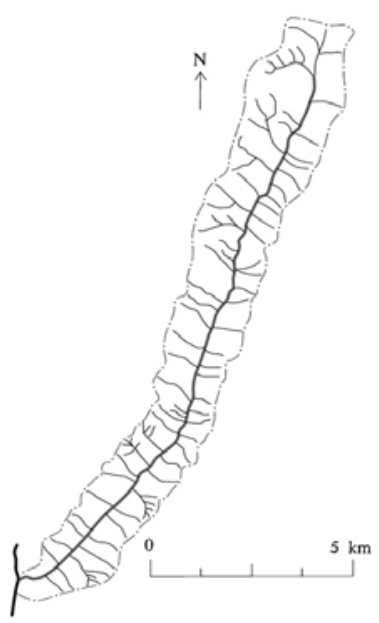

$\mathrm{b}$

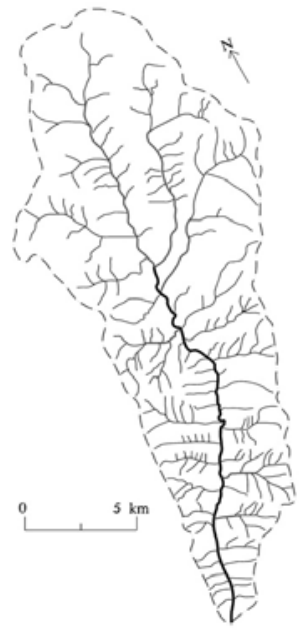

$\mathrm{c}$

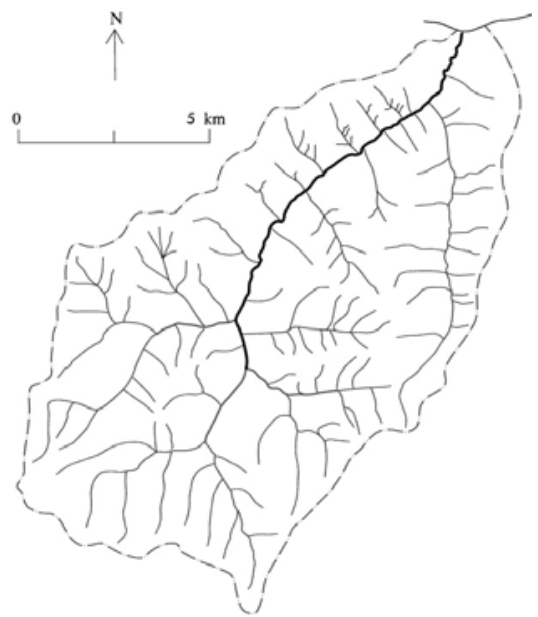

FIGURE 5. Stream networks extracted from satellite images: a - source of Dadu River; $b$ - source of Yellow River near Kesheng (Maqin County); and c - source of Yellow River near Maqin county town

invariant for different stream orders but it has a great range for plume networks. Hence, while dendritic networks may show remarkable similarity in physical structure between large and small watersheds, these relationships may be very different for plume networks. The stream network of the Dadu River shown in Figure $5 \mathrm{a}$ is consistent with results from plume networks, while networks in the source region of the Yellow River near Kesheng and Maqin are similar to results from nervation networks (these three networks are plotted on Fig. 6). 


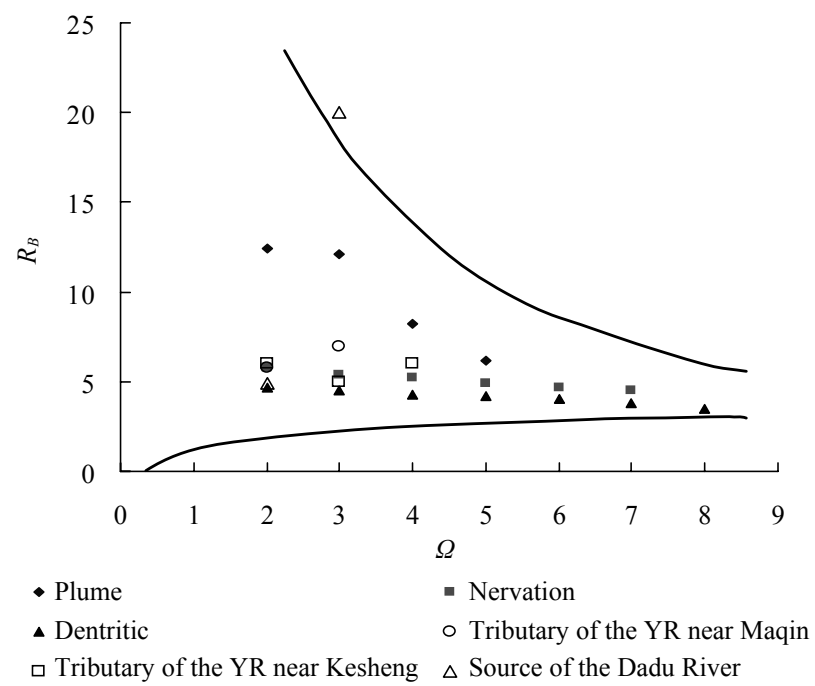

FIGURE 6. Comparison of bifurcation ratios for differing types of stream network, highlighting comparisons for the networks shown in Figure 5

It would be interesting to relate these results of stream network analyses to differing lithological considerations and associated linkages to tectonic setting. Indeed, comparison of networks atop the Qinghai-Tibetan Plateau with those in the Sichuan Basin could be used to assess tectonic imprints upon stream networks, prospectively determining various stages in the evolution of drainage networks and patterns.

\section{KNICKPOINTS AND THEIR EFFECT ON RIVER STABILITY}

Uplift of the Qinghai-Tibetan Plateau has caused significant bed incision along almost all rivers. Incision is deepest at the margin of the plateau. The longitudinal profile of the Minjiang River is related to the elevation of the adjacent mountain range in Figure 7. Depth of incision shown by the difference in elevation between the mountains and the channel bed is more than $2000 \mathrm{~m}$. Incision has resulted in very steep and unstable slopes adjacent to channels. Earthquakes and rainstorms trigger many landslides and avalanches, some of which may dam rivers and form barrier lakes. These natural dams protect bedrock from fluvial incision and knickpoint migration, helping to stabilize the margin of the plateau in concert with the effects of localized rock uplift (Korup et al. 2009). The slope below a landslide dam is steep but the upstream slope is very gentle. Hence, these knickpoints prohibit a river from eroding its bed and incising upstream. This continues as long as the landslide dams are not broken and scoured away. A landslide dam may develop into a knickpoint if it is stabilized under the long-term action of flow. Large boulders and cobbles are rearranged to form step-pool systems (Todd and Mike 2003; Whittaker and Jaeggi 1982). These features create great resistance and consume considerable flow energy, thereby 
protecting the channel bed from erosion ries of these features, may stabilize large as well as creating habitat for benthic knickpoints as several steps with very invertebrates (Milzow et al. 2006; Nicko- high slope (Wang et al. 2009d). The total lotsky and Pavlowsky 2007; Wang et al. water head of a large knickpoint can be 2009c).

Large knickpoints at the margin of the Qinghai-Tibetan Plateau range in elevation from 1000 to $4000 \mathrm{~m}$. Preservation of landslide and avalanche dams, or a seas large as several hundred meters. The Hutiaoxia (Tiger Leaping Gorge) landslide and avalanche dam on the Jinsha River has a water head of $213 \mathrm{~m}$. Several large knickpoints at Hutiaoxia, Deqin,

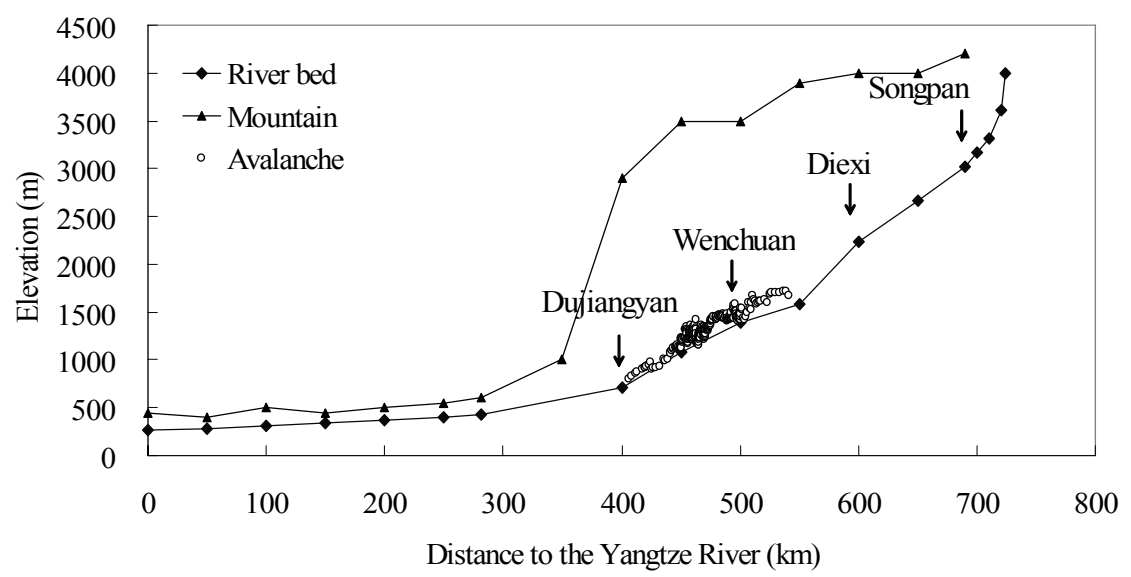

FIGURE 7. Longitudinal bed profile and elevation of the adjacent mountain ranges along the Minjiang River

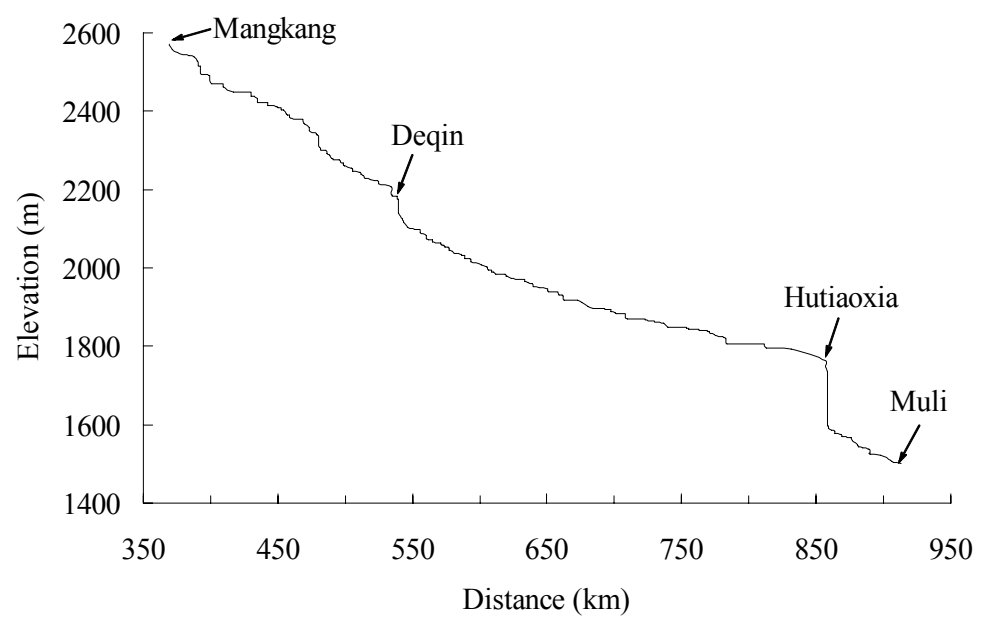

FIGURE 8. Bed profile of the Jinsha River showing the large knickpoints at Hutiaoxia (Leaping Tiger Gorge), Deqin and Mangkang 
and Mangkang are shown along the longitudinal profile of the Jinsha River in Figure 8. The Hutiaoxia landslide and avalanche dam created a large barrier lake upstream (Fig. 9). Although the discharge of the river is about $4,000 \mathrm{~m}^{3} / \mathrm{s}$ the water surface in the barrier lake was as smooth as a mirror because of the huge depth and low flow velocity. The lake traps all bedload and a large portion of the suspended load. The lake has not yet been filled because it was created quite recently and the relatively low sediment loads from upstream. A resilient step-pool system with huge hydraulic jumps has developed downstream of the barrier lake, consuming most of the flow energy and protecting the river bed from erosion.

Large knickpoints may totally change patterns of fluvial processes and river morphology. Figure 10a shows the bed profile of the Yellow River from the source (Erlin Lake) to Longyangxia Dam - the uppermost large dam on the river. Two large knickpoints are evident:

a

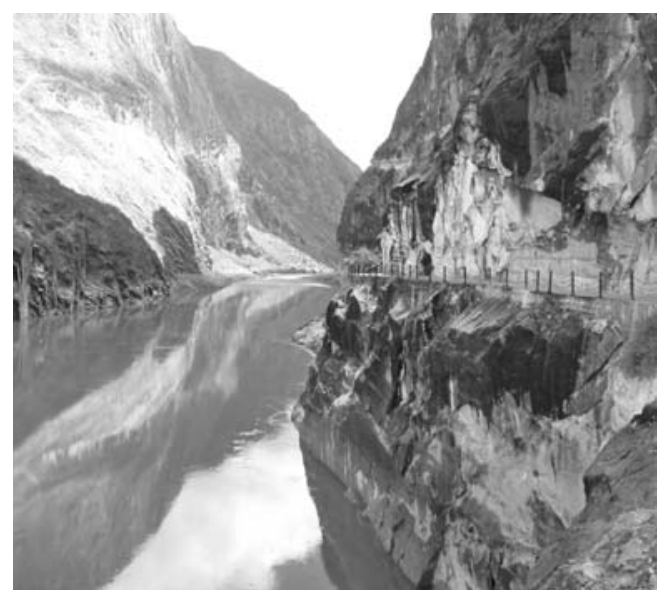

immediately downstream of Dari County town and downstream of Kesheng Town. Several landslide dams, with large barrier lakes upstream, characterize these knickpoints. These barrier lakes have been infilled by this sediment-laden river. Figure $10 \mathrm{~b}$ shows a part of the Kesheng knickpoint, which consists of several landslide dams and barrier lakes. The transition from landslide dams into large knickpoints has greatly influenced river profiles and landscape evolution. The longitudinal bed profile of the Yellow River in the $1,400 \mathrm{~km}$ long reach is very unusual, with a convex upward curve caused by the two large knickpoints. Harkins et al. (2007) report a similar phenomenon for tributaries of the Yellow River. Downstream reaches are steep but incision is controlled by step-pool systems. Upstream reaches have adjusted to a new, unchanging base level.

Cross sections from the upstream section and the landslide dam section of the Dari and Kesheng knickpoints are pre-

b

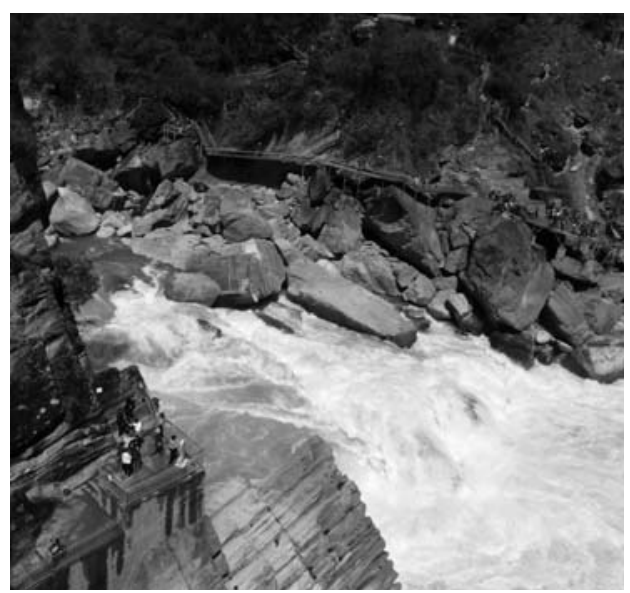

FIGURE 9. a - Hutiaoxia barrier lake; b - Part of the step-pool system on the Hutiaoxia landslide dam 
a

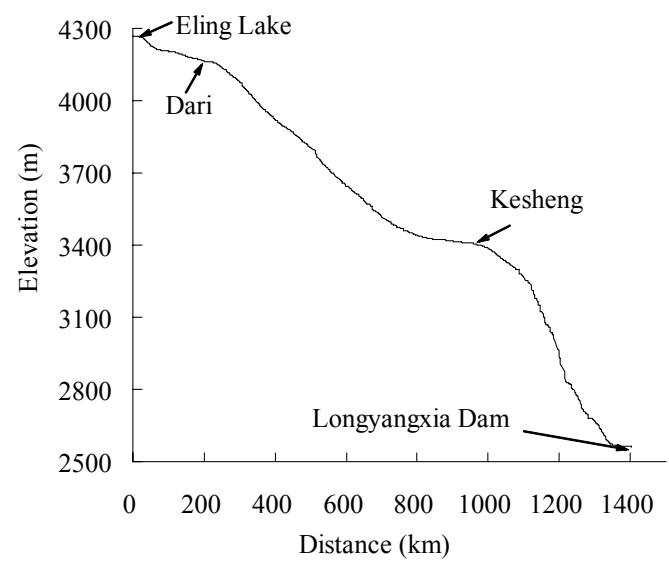

b

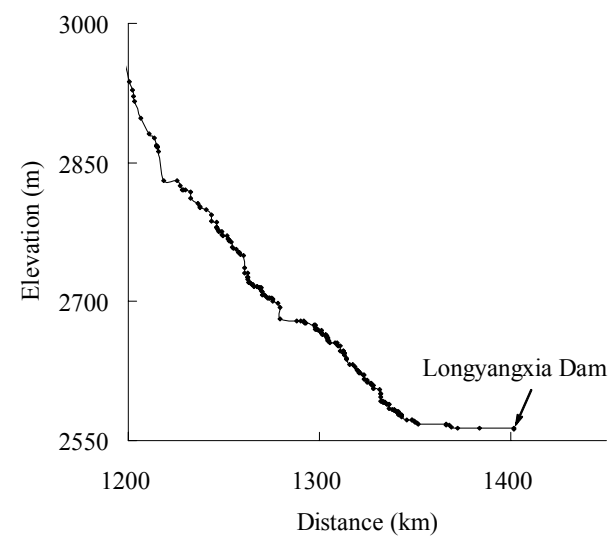

FIGURE 10. a - Bed profile of the Yellow River from the source (Erlin Lake) to Longyangxia Dam; $\mathrm{b}$ - Part of the Kesheng knickpoint consisting of several landslide dams and barrier lakes

a

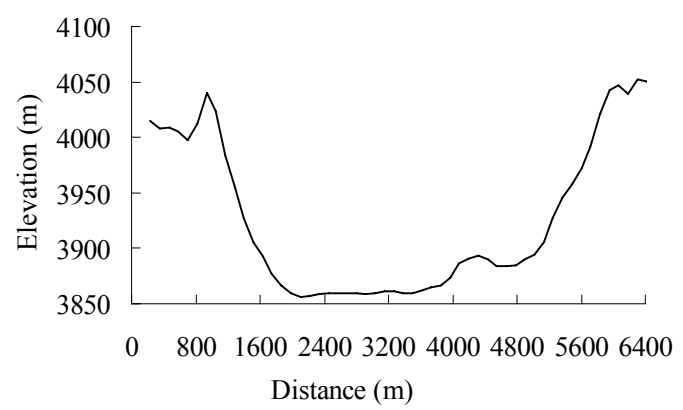

c

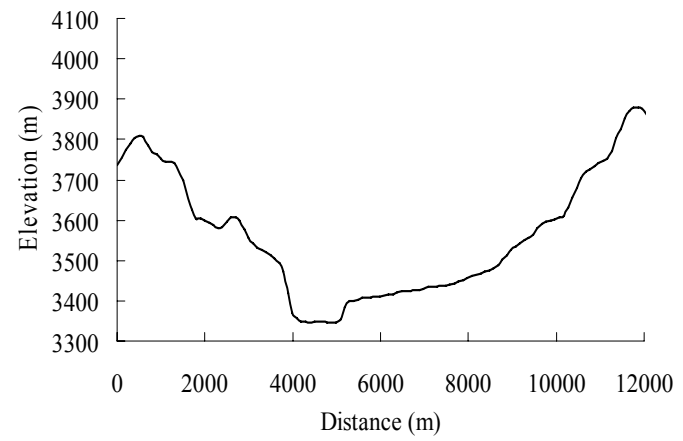

b

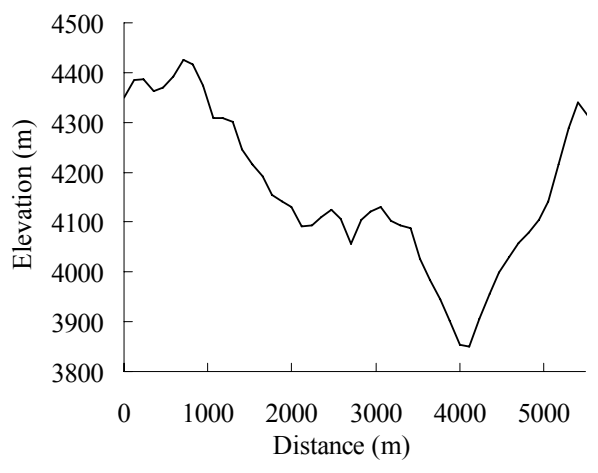

d

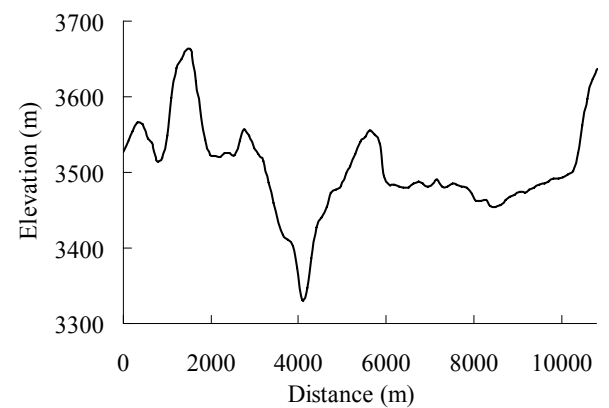

FIGURE 11. $a$ - Cross section upstream section of the Dari knickpoint; $b$ - Cross section of a landslide dam at the Dari knickpoint; c - Cross section upstream of the Kesheng knickpoint; d-Cross section of a landslide dam of the Kesheng knickpoint 
sented in Figure 11. Landslides evident on the left hand side of Figure 11b and the right hand side of Figure 11d likely dammed the river and influenced the generation of knickpoints. Accumulation of huge boulders on the bed formed a stable step-pool system that is strong enough to resist the flow and protect the bed from erosion. Long term aggradation following knickpoint formation has resulted in wide and shallow cross sections in upstream areas, whereas the landslide dam section itself is narrow and deep. The distribution of channel processes and resulting river morphologies, have adjusted to these damming events. Localized aggradation upstream of knickpoints has brought about a transition from vertical bed evolution to horizontal fluvial process. Reduction in slope and accumulation of fine-grained sediments has facilitated the development of anabranching and braided channel planforms (e.g. just upstream of Dari, Fig. 12).

\section{CONCLUSIONS}

Over time the uplift of the Qinghai-Tibetan Plateau and the relative movement of the Earth's crust at the margins of the plateau has modified river alignment, resulting in asymmetrical stream networks for the Minjiang, Tuojiang, Fujiang and Jialing Rivers and their tributaries. Almost all of these rivers flow from the northwest to the southeast. Asymmetry is also evident for midsize rivers (e.g. more than $90 \%$ of the drainage area of the Xihanshui River is on the western side of the river).

Much of the Sanjiangyuan region is dominated by nervation stream networks, with some plume types. The bifurcation ratio of these networks is high for second order and third order streams and reduces with increasing in stream order. The ratio is around 4 for stream order large than 8 .

Uplift of the Qinghai-Tibetan plateau has caused extensive channel bed inci-

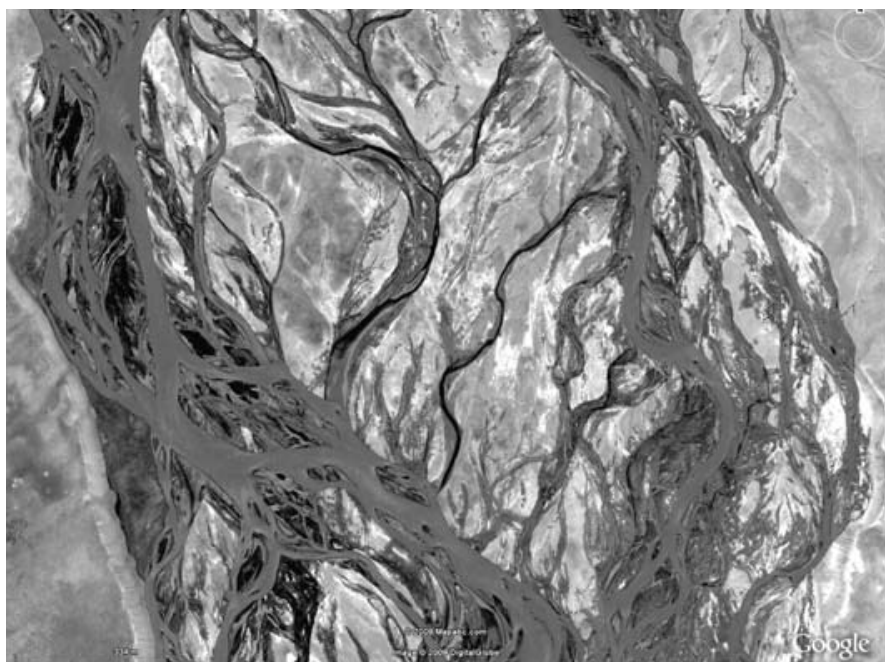

FIGURE 12. Satellite image of the branching channels upstream of the Dari knickpoint 
sion along almost all rivers. In some instances this exceeds $2,000 \mathrm{~m}$. This has created great potential for landslides and avalanche activity. A landslide dam may develop into a knickpoint if it is stabilized by the long-term action of flow. Large knickpoints have totally changed the distribution of fluvial processes and resulting river morphology in some reaches of the source zone of the Yellow River. Longitudinal profiles are reshaped by the distribution of knickpoints. Although reaches downstream of knickpoints are steep, incision is controlled by step-pool sequences that consumes the majority of the flow energy and protect the river bed from erosion. Upstream reaches have a new, unchanging base level. This brings about a transition from degradation to aggradation and from vertical bed evolution to horizontal fluvial process. Multiple and unstable channels are prominent in the reaches upstream of the knickpoints.

Acknowledgement: The study is supported by the Sino-New Zealand collaboration research project, Ministry of Science and Technology of China (2008CB425803 and 2007SHZ0901034). We are grateful to Prof. Heqing Huang, Chinese Academy of Sciences, for his support to this study.

\section{REFERENCES}

CHEN J., GAVIN H., 2008: Finite Fault Model of the May 12, $2008 \mathrm{Mw} 7.9$ Eastern Sichuan, China Earthquake. United States Geological Survey - National Earthquake Information Center. http://earthquake.usgs.gov/, Retrieved 2008-05-15.

CHIN A., 2002: The periodic nature of step-pool mountain streams. American Journal of Science. 302: 144-167.
CICCACCI S., D'ALESSANDRO L., FREDI P., 1992: Relation between morphometric characteristics and denudation processes in some drainage basins of Italy. Zeitschrift für Geomorphologie. 36(1): 53-67.

COSTA J.E., SCHUSTER R.L., 1988: The formation and failure of natural dams. Geological Society of America Bulletin. 100: 1054-1068.

DONG GUANGRONG, WANG GUIRONG, CHEN HUIZHONG, YAN MANCUN, JIN JIONG, WANG YUE, 1994: The formation and evolution of the deserts in China and their relation to the uplifting of Qinghai-Tibet Plateau. Proceedings of Qinghai-Tibetan Plateau and Global Variations, 13-29. (in Chinese)

HARKINS N., KIRBY E., HEIMSATH A., ROBINSON R., REISER U., 2007: Transient fluvial incision in the headwaters of the Yellow River, northeastern Tibet, China. Journal of Geophysical Research. F. Earth Surface. 112, F3.

HORTON R.E., 1945: Erosional development of streams and their drainage basins: hydrophysical approach to quantitative morphology. Geological Society of America Bulletin. 56: 275-370.

KINNER D.A., MOODY J.A., 2005: Drainage networks after wildfire. International Journal of Sediment Research. 20(3): 194-201.

KIRCHNER J.W., 1993: Statistical inevitability of Horton's laws and the apparent randomness of stream channel networks. Geology, 21: 591-594.

KORUP O., MONTGOMERY, D.R., HEWITT K., 2009: Spatial clustering of natural dams at the Tibetan Plateau margin in rivers draining the Himalayan syntaxes. Geophysical Research Abstracts. 11: EGU2009-8344

KORUP O., STROM A., WEIDINGER J., 2006: Fluvial response to large rock-slope failures: Examples from the Himalayas, the Tien shan, and the southern Alps in New Zealand. Geomorphology, 78(1-2): 3-21.

KORUP O., 2004: Geomorphometric characteristics of New Zealand landslide dams. Engineering Geology. 73: 13-35.

LIU HUAIXIANG. Research on the Distribution of Streambed Structures and Their influence on Fluvial Morphology. Doctoral dissertation, Tsinghua University, 2009 (in Chinese).

LIU H.X., WANG Z.Y., 2008: Morphological feature and distribution of typical river networks. 
Journal of Hydraulic Engineering. 38(11): 1354-1357 (in Chinese).

MILZOW C., MOLNAR P., McARDELL B.W., BURLANDO P., 2006: Spatial organization in the step-pool structure of a steep mountain stream (Vogelbach, Switzerland). Water Resources Research. 42: W04418.

NICKOLOTSKY A., PAVLOWSKY R.T., 2007: Morphology of step-pools in a wilderness headwater stream: The importance of standardizing geomorphic measurements. Geomorphology. 83: 294-306.

OUIMET W.B., WHIPPLE K.X., ROYDEN, L.H. SUN ZHIMING, CHEN ZHILIANG, 2007: The influence of large landslides on river incision in a transient landscape: Eastern margin of the Tibetan Plateau (Sichuan, China). Geological Society of America Bulletin. 119 (11/12): 1462-1476.

TANG MAOCANG, DONG WENJIE, 1997: Influences of seven Tibet Plateau raising processes on climate and environment. Plateau Meteorology, 16(1): 23-29 (in Chinese).

TODD M., MIKE L., 2003: Natural channel design of step-pool watercourses using the "key-stone" concept. ASCE conference process. 18: 1-11.

WANG ZHAOYIN, CUI PENG, WANG RUIYU, 2009a: Mass movements triggered by the Wenchuan Earthquake and management strategies of quake lakes. International Journal of River Basin Management. 7(1): 1-12.

WANG ZHAOYIN, LEE J.H.W., MELCHING C.S., 2009b: Integrated River Training and Management, Springer Verlag and Tsinghua Press, Berlin and Beijing.

WANG ZHAO-YIN, MELCHING C.S., DUAN XUEHUA DUAN, YU GUO-AN, 2009c: Ecological and hydraulic studies of step-pool systems, ASCE Journal of Hydraulic Engineering. 134(9): 705-717.

WANG ZHAOYIN, SHI WENJING, YU GUOAN, QI LIJAN, 2009: New challenges of river management induced by the Wenchuan Earthquake. Hydroscience and Engineering. 4: 1-11 (in Chinese).
WANG ZHAO-YIN, WAI ONYX W., CUI PENG, 1999: Field investigation into debris flow mechanism. International Journal of Sediment Research. 4: 10-22.

WHITTAKER J.G., JAEGGI N.R., 1982: Origin of step-pool system in mountain streams. Journal of the Hydraulics Division, ASCE. 108: 758-773.

Streszczenie: Rozwój progów skalnych oraz morfologia rzek w regione Sanjiangyuan. W artykule przedstawiono proces rozwoju progów skalnych wzdłuż rzek Yellow i Yangtze. Wykazano wpływ progów skalnych na zmiany morfologiczne dna koryt rzek. Głównie skoncentrowano się na zmianach agradacyjnych powyżej omawianych progów. Progi te są wyznacznikami zmian charakteru koryta rzecznego, z pionowo wciętego na wielonurtowy, roztopowy o szerszym korycie. Badania wykonano w rejonie Qinghai_Tibetan Plateau, zwanym obszarem źródłowym trzech rzek - oprócz wyżej wspomnianych również rzeka Mekong.

\section{MS. received April 2010}

Authors' addresses:

\section{Zhaoyin Wang}

State Key Laboratory of Hydroscience and Engineering, Tsinghua University,

Beijing 100084, China

\section{Guo-An Yu}

Institute of Geographical Sciences and Natural

Resources Research

Chinese Academy of Sciences

Beijing 100101, China

Gary Brierley

School of Environment, University of Auckland

Le Liu

Department of Hydraulic Engineering

Tsinghua University

Beijing 100084, China

e-mail: zywang@tsinghua.edu.cn 